QAULAN, Vol. 2, No.1, Juni 2021

Imam Mukhlis, Media as a Social Contract....

\title{
MEDIA AS A SOCIAL CONTRACT: \\ DA'WAH RELATION AND MASS MOBILZATION 2016-2019
}

\author{
Imam Mukhlis \\ Institut Agama Islam Negeri Kediri \\ Mukhlisimam87@gmail.com
}

\begin{abstract}
Abstrak: The alleged case of blasphemy committed by Mr. Ahok in 2016 has become the most popular news of all time in this digital era. The case has a long tail and raises pros and cons among the public, especially among Muslims. What's more, some of the Islamic mass organizations have accused them of taking down the streets with certain political interests. All efforts were made by these religious activists to legally process Ahok, one of which was the call for jihad amar ma'ruf nahi munkar by utilizing several existing digital media. In scientific writing, the author uses several theory approaches (Mix theory) including the theory of sociology, da'wah and media as social constructions in determining collective action that exists during the 2016-2019 action to defend the Qur'an. The use of the media to mobilize the masses is considered a significant strategy to foster a sense of social solidarity that resulted in the 2016-2019 mass action. The translation of writing uses qualitative descriptive. This means describing the existing reality with a narrative/descriptive story. Based on the findings in the field, the researchers found several important points in this paper, including: The media has an important role as a tool to support da'wah. Second, the existence of a digital world will indirectly form a virtual community that does not rule out the possibility of a sense of social solidarity.
\end{abstract}

Keywords: The Role of Media, Virtual Communities and Digital Social Solidarity in the Ahok Case

\section{INTRODUCTION}

The words of da'wah cannot be separated from the religion of Islam, especially in the political year, religious activists are aggressively carrying out their dawah actions. It was recorded that in 20162019, especially in Indonesia, where this year can also be called the political year, many da'wah activists have sprung up. The author observes that the emergence of da'wah activists in 2016-2019 is nothing but the legitimacy of the opposition movement. The emergence of a veteran da'wah activist, Habib Rizieq, gave religion a color in the political year. So many stereotypes of his da'wah actions are often judged as a political movement. On November 4, 2016, Muslims held a large-scale demonstration in DKI Jakarta and in several major cities in Indonesia. This demonstration is hereinafter referred to as the Peace Action or better known as the Action 411 . Action 411 by many is considered a demonstration with the second largest mass escalation after the 1998 Action that has ever occurred in Indonesia. The 411th Action is the second demonstration carried out by 
QAULAN, Vol. 2, No.1, Juni 2021

Imam Mukhlis, Media as a Social Contract....

Muslims, after the 14th October 2016 Action which was aimed at DKI Jakarta City Hall. Action 411 involved a very large mass or demonstrator and came from various regions in Indonesia. ${ }^{1}$

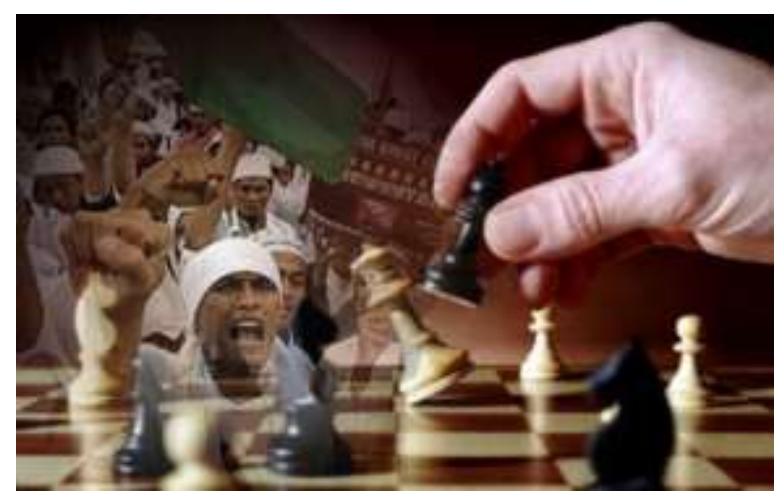

Source: Nu.or.id

Moreover, in the alliance of these groups there is an activist who openly broadcasts his da'wah against the government. For him, fighting against the government which is considered dzalim is part of the amar ma'ruf nahi munkar. It could be said, according to political writers in that year, it was necessary to have support from someone's faith who would strengthen the support of figures such as Habib Rieziq and Cak Nur Sugig (new preacher activists who emerged in the political year). Moreover, the movement was spearheaded by a Habib who was judged that the movement and its actions had the blessing of the Prophet Muhammad SAW. Of course, this will be a plus in itself so it will be easy to get sympathizers or support from the community, especially those who are Muslim.

Of course this is not a new thing for religion in Islam. In the history of Islam, precisely at the time of Caliph Ali, religion and the arguments of the Qur'an became the legitimacy of the da'wah movement carried out by the Khawarij to overthrow and kill Ali. In other words, if we look at the socio-religious movement from a political perspective, then religion becomes a platform for politics and da'wah activists become the driving force. So that in that political year, da'wah activities carried out by da'wah activists have been ridden by certain political interests. So in this paper, the author will discuss the relationship between da'wah and mass mobilization.

On this occasion, the author will explain how the relationship between the role of digital social media as a tool for da'wah activities carried out by religious activists at that time involved hundreds of Muslims coming from remote parts of the archipelago to take action on the streets..

${ }^{1}$ The Indonesian Institute, Center for public policy research "Úpdate Indonesia" volume X No 11 November 2016 hal 1 
QAULAN, Vol. 2, No.1, Juni 2021

Imam Mukhlis, Media as a Social Contract....

\section{THEORETICAL FRAMEWORK}

In scientific writing, the author uses several theories (Mix theory) including the theory of sociology, da'wah and media as social constructions in determining collective action that exists during the 2016-2019 action to defend the Qur'an. The use of media to mobilize the masses is considered a significant strategy to foster a sense of social solidarity that results in the 2016-2019 mass action.

\section{a) Da'wah}

The term da'wah in Islam means a call or invitation. While the terminology of da'wah means inviting or calling on others. While some experts explain that, da'wah is a job or a motivating speech with the aim of influencing someone to follow the beliefs they hold. So almost all Muslims, da'wah becomes an obligation. Because for Muslims, da'wah is a noble task for a Muslim so that he will get the title as khoirul ummah (ie the best of the people). While the implementation and purpose of da'wah itself can be in the form of increasing faith and piety, increasing welfare or upholding justice. $^{2}$

From the above understanding, da'wah activities can be carried out in various ways and various media, both oral and written (da'wah bi al-ihsan and bi al-qalam). Even in the political year, da'wah can be done with actions (da'wah bi al-hal) and a social-Islamic action (bi ahsan al-amal). If this da'wah activity is related to its influence on human behavior in social life, then in sociological analysis, religious teachings are a social reality. This fact is a sociological phenomenon about human behavior. In addition, religion also has an impact on everyday human life. Because in religious teachings there is a value system that contains certain norms. And these norms become the basis of reference in behaving and behaving. ${ }^{3}$

\section{b) Media and Social Constructionia}

The news that has been presented by the mass media is actually the second reality. The information presented is actually not necessarily like that, but has gone through the construction process of the media concerned. The construction of social reality occurs through the process of interaction and communication, in this context what is meant by interaction and communication is the contact or exposure of the public to the media. The term social construction of reality was introduced by Peter L. Berger and Thomas Luckman in their book The Social Construction of

${ }^{2}$ Hajir Tajiri dan Enjang (ED). Etika Dakwah (T.W. Padjadjaran, 2009) hal, 1.

3 Indra latif syaepu Kerukunan Antar Umat Beragama di Desa Besowo Kecamatan Kepung Kabupaten kediri: Studi Terhadap Peran Elit Lokal dan Masyarakat dalam Melestarikan Kerukunan. Universitas Islam Negeri Yogyakarta, 2016. 
QAULAN, Vol. 2, No.1, Juni 2021

Imam Mukhlis, Media as a Social Contract....

Reality: A Treatise in the Sociological of Knowledge (1966). It describes social processes through their actions and interactions, in which individuals create continuously a reality that is shared and subjectively shared. For Berger, reality is not formed scientifically or naturally derived by God, but on the contrary it is shaped and constructed. ${ }^{4}$

In the book Introduction to Communication Theory, the characteristics of mass communication, among others, "goes in one direction, communicators in mass communication are institutionalized, messages are general, give birth simultaneously, and communicants are heterogeneous. In addition, the characteristics of mass communication are being able to reach a wide audience, there is always a selection process, trying to target certain social targets and communication is carried out by social institutions that must be sensitive to environmental conditions.

The characteristics of mass communication include being able to touch or reach the wider community. It means the whole society at large which consists of all different layers, elements and backgrounds. In addition, it can target certain social targets and communication is carried out by social institutions that must be sensitive to environmental conditions, such as the da'wah message conveyed by religious activists in the case of the Al-Qur'an defense action which resulted in the mass action of Muslims.

\section{METHOD}

In this method of writing, the authors obtain data from several media in the form of audio, visual and print and observe the public opinion that is formed. While the method of analysis, the author uses the glasses of sociology, social movements and identity politics. While the design in writing this scientific paper, the author collects as much data as possible and analyzes it. ${ }^{5}$ As for the design of the validity of the data, the data analysis process starts from reviewing the overall data from various sources. In this paper, the authors use triangulation. ${ }^{6}$

\section{DISCUSSION}

Mass media is one of the important elements in democratic life to connect the community with the government. The relationship between the press and the government can be said to be a symbiotic

${ }^{4}$ Eriyanto. 2002. Analisis Framing - Konstruksi, Ideologi, dan Politik Media. Yogyakarta: LKIS. 18.

${ }^{5}$ Suharsini Arikunto, Prosedur Penelitian Suatu Pendekatan Praktek, Jakarta: Bhineka Cipta, 1998, 89

${ }^{6}$ Sugiyono, Metode Penelitian Kombinasi Mixed Methods (Bandung: Alfabeta, 1953), hal 369. 
QAULAN, Vol. 2, No.1, Juni 2021

Imam Mukhlis, Media as a Social Contract....

mutualism, a mutually beneficial relationship. Mass media is present as a provider of all forms of information related to the world of government when not just anyone can reach it. The information presented also varies, including religious teachings. So we often encounter some religious activists using several media to influence the masses.

Today, a lot of changes are happening in the field of communication. Starting from a simple form of communication to electronic communication. This rapid change, especially in the 20th century, some experts say is a communication revolution. This rapid change is driven by various inventions in the field of technology so that what used to be an obstacle in communication activities is now wide open. A person can relate to a person or group of people without being limited by time, distance, number, capacity and speed factors. For example, the use of satellites in communications.

An interesting trend that can be seen in recent years is that along with the emergence of smart gadgets and smartphones, the nuances of multimedia da'wah can also be felt. Religious nuanced applications can be enjoyed starting from sms services, digital al-Qur'an, GPS Qibla, digital Murattal and so on. All of this indicates that Islamic da'wah is no longer limited to textual but also contextual. The future mass da'wah will continue to develop and be dynamic in line with the dynamics of the times. The ability to adapt to developments has become a belief for da'wah actors.

They are required not only to be able to present Islam in an actual way but also to convey Islamic teachings comprehensively. In the future, da'wah in ta'lim assemblies will begin to shift from the real world to the virtual world. This tendency has been widely seen from the rise of religious lectures uploaded to You Tube or similar media capable of storing digital data that can be uploaded by anyone in any part of the world. Seeing the tendency of da'wah itself that the essence of the content of da'wah messages is da'wah messages conveyed to da'wah partners. As in the case of 2016-2020, the mass media are filled with calls for jihad amar ma'ruf nahi munkar.

Since 2016-2019 the world has witnessed the rise of fundamentalism accompanied by Islamic radicalism in Indonesia, especially Jakarta. One of the organizations that has garnered the most attention thanks to its involvement in a number of radical acts and terrors in Indonesia which is considered to have caused a lot of unrest, namely the Islamic Defenders Front (FPI). The majority of writings discussing the contemporary development of Islamic radicalism also understand the 
QAULAN, Vol. 2, No.1, Juni 2021

Imam Mukhlis, Media as a Social Contract....

actions of hard-line Muslim activists as an effort to realize the goal, namely the implementation of Shari'a, the establishment of an Islamic state or the establishment of a caliphate. ${ }^{7}$

In the 2010s, the organization led by Habib Rizieq carried out a campaign against prostitution, pornography, alcohol, drugs and gambling. In the past such campaigns, which often ended with physical attacks on places such as bars, pubs, cafes, nightclubs, discotheques, massage parlors, casinos and billiard houses, were carried out spontaneously by local Muslims around these immoral places. . If we look further and deeper in 1999, anti-immorality campaigns often take place in the period before and during the month of Ramadan. Because radical activists regard Ramadan as a holy month, they always demand the local government to close down places of immorality.

If the government does not comply with the request, groups like FPI will take the initiative on their own. In one incident, FPI even bravely occupied the office of the DKI Jakarta regional government when the local government closed entertainment centers only on the first two days of Ramadan and not for the whole month. But in many cases FPI and other sectarian groups often hold anti-immorality campaigns without first asking the government's permission. They are quite confident in carrying out actions that clearly violate legal signs without fear of being penalized. Especially, because groups like the FPI have close ties to a number of Indonesian political elites.

In the early days of the anti-immorality campaign, the police were almost powerless to face the actions of radical groups. When the police finally succeeded in detaining the FPI member involved in the physical assault, the organization condemned the arrest as immoral while justifying his actions. After Rizieq's detention in 2002 the number of acts of violence against entertainment venues decreased dramatically.

However, in the 2016 - 2020 case, radical activists conducted mass marches to voice their demands and to introduce themselves to the Indonesian public. In recent years HTI and FPI have played a major role in mobilizing radical Muslims to stage street protests. However, in the case of this action, something is slightly different, it is no longer purely a religious movement, but there is a political element that rides it. ${ }^{8}$

Starting from the viral case of the 2016 Q.S Al Maidah interpretation video conducted by Mr. Basuki Tjaja Purnama on Pramuka Island, the Thousand Islands, which is considered to have

${ }^{7}$ Indra latif Syaepu Radikal Dulu, Teroris Kemudian: Gerakan Islam "garis keras" dulu dan kini Dalam tinjauan sosial-historis (STAIN Kediri: Emperisma juli 2017) Hal 10

${ }^{8}$ Sejumlah berita menyorot aksi terebut dinamakan aksi bela Al qur'an yang kemudian berubah menjadi aksi bela Islam, aksi 212, GNPF MUI sampai aksi bela ulama. 
QAULAN, Vol. 2, No.1, Juni 2021

Imam Mukhlis, Media as a Social Contract....

committed blasphemy against religion. Mr. Ahok's words, quoting Q.S Al Maidah, also had a long tail, causing debate among Muslims. As a result, some of the Muslims felt offended and angry and took action to take to the streets. This action is known as the Action to Defend the Qur'an.

The demonstrators demanded that the authorities continue to process Ahok on charges of blasphemy. To avoid mass movements that continue to spread, President Jokowi asked the police to process the law openly and transparently. Although initially open, but the proceedings took place behind closed doors. As if dissatisfied with the results of the trial and a negative stigma emerged assuming that Ahok was protected by law. But on the other hand, the issues of the collective movement carried out by these mass organizations have been used or ridden by political interests related to office seats in Jakarta.

As a result, news circulated in several media, that the Muslims who took the action down the street were paid people who had certain goals. The demonstration that started peacefully became anarchic, causing riots and the destruction of public facilities so that they were considered disturbing and detrimental to the surrounding community. The demonstration that ended in anarchism was also highlighted by several local, national and international media, which made the Islamic community who were not involved in the action feel ashamed. The anarchic actions carried out by the protesters are considered to have harmed the religion of Islam or are not in accordance with Islamic teachings. And in the end it causes internal divisions among Muslims.

\section{a. Strengthening social solidarity in the digital era}

The media is a very powerful tool in attracting public support, and relating to public opinion. How the media constructs can lead to different audiences' understanding of the same event or reality. Therefore, the media must be seen as a place where every group with an interest in a reality fights each other for public support, and constructs each other's reality according to their interests as well. This construction can be used to convince the audience that a particular event is a major event that must receive careful attention from the audience.

After reading the background above, it is true that sometimes politics requires legitimacy from religion as a trick to get support. Social media is now starting to be used to act as an agent of group solidarity. This is due to the fact that the world has entered the digital age. Of course, it is marked by the presence of information and communication technology which will continue to grow rapidly. In the process of information massification, technology plays a role in changing communication patterns that were previously limited by space and time into unlimited communication patterns. Advances in information and communication technology now allow 
people to find and utilize information sources to meet their needs in real time through an internet connection, including in this case the religious case that occurred in 2016 - 2019.

The activists who preach this strategy are considered good enough to get sympathizers from the community, especially those who are Muslim. Utilization of the development of information technology as a medium of da'wah has been put to good use by these religious activists. In an effort to organize a collective social movement, in this case a mass action involving thousands of Muslims from all over the archipelago, solidarity is needed. Thus, the sense of solidarity is able to foster an attitude in the form of sacrificing time, money, thoughts and energy for a common goal. To foster an attitude of solidarity involving hundreds of people from various regions in the archipelago, da'wah activists utilize existing technology media, especially social media.

Social media is considered capable of disseminating information massively and immediately (ontime). Social media is a place or means to move discourse, opinion and argument. So that indirectly the impact of this media has an impact on existing realities, such as the formation of small groups in society that have the same sense of connection and bring about solidarity. That is, social media here is a form of mass communication. Mass communication is a type of human communication that was born at the same time as the use of mechanical devices capable of multiplying communication messages.

According to Deddy Mulyana in Introduction to Communication Science defines mass communication as communication that takes place in an interposed situation when there is no direct contact between the source and receiver, communication messages flow to recipients through mass media channels, such as newspapers, radio, films, or television. Communication using mass media, whether printed (newspapers, magazines) or electronic (radio, television) managed by an institution or institutionalized person, is addressed to a large number of people who are scattered in many places, anonymous, and heterogeneous. The messages are general, delivered quickly, simultaneously and at a glance. ${ }^{9}$

Before we discuss the main theme, the author will first discuss solidarity from a social point of view or the sociology of religion. In sociological theory, religion plays a vital role in providing the forces that support and strengthen customs. In this connection, it should be noted that the attitude of exalting and respect, especially with the prevailing customs (morals). The role of

${ }^{9}$ Deddy Mulyana Pengantar Ilmu Komunikasi (Bandung. Remaja Rosda Karya. 2005) HAL 75 
QAULAN, Vol. 2, No.1, Juni 2021

Imam Mukhlis, Media as a Social Contract....

religion in the social field is to create a common bond, both among members of several societies and in social obligations that help unite them..$^{10}$

The concept of social solidarity is a collective concern for a group that refers to a state of relationship between individuals and other individuals or groups with other groups based on moral equality, the same collective and shared beliefs and reinforced by emotional experience. The principle of social solidarity is mutual help, cooperation and sharing. Which will strengthen the internal unity of a group.

Social solidarity is also influenced by social interactions that take place because of cultural ties. One source of solidarity is gotong royong. The gotong royong tradition in question includes mutual help activities within the group. According to Emile Durkheim, society needs solidarity. This solidarity includes social glue, customs and beliefs shared by community members in a collective bond and consciousness. ${ }^{11}$

In the digital era, Indonesian people are active in using the internet. Automatically also active in utilizing existing media, including social media. Activities between individuals in the digital world that will form a digital network society. The emergence of a new world, namely the digital world, allows the emergence of social groups and forms social participation via digital through posts that appear. One example is the case of blasphemy against Ahok in 2016 which made some Muslims from certain groups feel angry with him.

Digital social solidarity in question is an act of communication between digital and at the same time as a form of mass mobilization effort. If it is related to the blasphemy case carried out by Ahok, they are aware of the importance of building digital social solidarity to mobilize the masses and support their actions. Efforts to seek support by using the media continuously is a collective awareness for these organizations to get many sympathizers and support from various circles of Muslims scattered throughout the archipelago.

Digital social solidarity is a collective action that is not uncommon in today's digital era. Moreover, the social media campaign on the issues of collective action 411 or known as the Action to defend the Qur'an in 2016. The use of the term hashtag is no stranger to the world of social media. The purpose of the hashtag itself is to cover a number of issues with the aim of building perceptions and creating social awareness as well as an invitation to participate. These actions can be called a social media campaign.

${ }^{10}$ K.Notthingham elizabeth. "agama dan masyarakat suatu penghantar sosiologi agama". (jakarta: PT RajaGrafindo, 1994$), 36$.

11 Ambo upe "tradisi aliran dalam sosiologi dari filosofi positivistic ke post positivistic" (Jakarta: PT RajaGrafindo persada,2010), 95 . 
Social media campaign activities in the Ahok case are considered very important to be carried out in order to reach many sympathizers and form digital social solidarity. Moreover, with the religious argument of jihad amar ma'ruf nahi munkar as the legitimacy of the collective actions that will be carried out. Digital social solidarity arises because of the existence of a virtual community, while the emergence of virtual communities arises on the basis of ties to something that is considered the same.

One of the virtual communities in which there is a sense of digital social solidarity, namely the 212 alumni community which is based on the teachings of religious values in the form of the motto Amar ma'ruf nahi munkar. The important point of this article is that the existing social media is a space to foster a sense of micro-level solidarity that is not limited by distance and time.

\section{b. Religious Activists: the role of da'wah and the theme of da'wah 411 - GNPF MUI}

What is meant by religious activists here is the mention of religious figures in the cases of defending the Qur'an and 212. As we know, the religious social movements from the 411 to the GNPF MUI movement apart from being pioneered by Habib Rizieq, there are also several other religious figures who are considered to be have prestige in the eyes of society. Every religious figure (ulama) in reality always has followers. Ulama and religious leaders are local elites who have their own charm in the eyes of the community. Ulama means experts in science or experts in knowledge or scientists. ${ }^{12}$ Ulama are people who are high and in their knowledge of the religion of Islam and become examples of exemplary in practicing that religion in their lives. ${ }^{13}$

Apart from scholars, there are also religious figures. According to some references that the authors get related to the term religious figures are slightly different from the ulama. Religious leaders are religious teachers who come from ordinary people who pursue various religious sciences so that they gain sufficient knowledge. Of course, in this case, there are differences between religious leaders from one another, it all depends on the capabilities of each, because everyone has a different level of intelligence. Religious leaders are people who have advantages in the field of religion and religion over society in general. From this capability and competence he has, making a religious figure a person who is respected among the community, because the dose of piety and religious insight is very broad and deep..$^{14}$

${ }^{12}$ Taufik Abdullah, Agama dan Perubahan Sosial ( Jakarta: CV Rajawali, 1983), hal 3

${ }^{13}$ Ibid 308.

${ }^{14}$ Ibid 10. 
As a central figure in society, especially in the 411 collective social movement to the GNPF MUI, of course, the role of religious activists in awakening the weak spiritual spirit, especially young people, is very urgent. The reality is that religious activists have a very big influence in society. All decisions "whether legal, social, religious or political" must be in accordance with those advocated by the religious activists, ${ }^{15}$ such as at the beginning of the 411 movement that occurred in 2016 religious activists called for Ahok to be punished by law, because he was considered to have insulted the holy book of the Qur'an, especially the interpretation of Q.s $\mathrm{Al}$ Maidah. The rejection of Ahok is increasingly being carried out by people who are pro-mass organizations, not only in the pulpit of the mosque and mosque, but also in the digital world, especially in the Greater Jakarta area. The divisions among Muslims also began to occur among the people, especially in Jakarta, which resulted in the rejection of the funeral prayer in the Musola or Mosque for Ahok supporters.

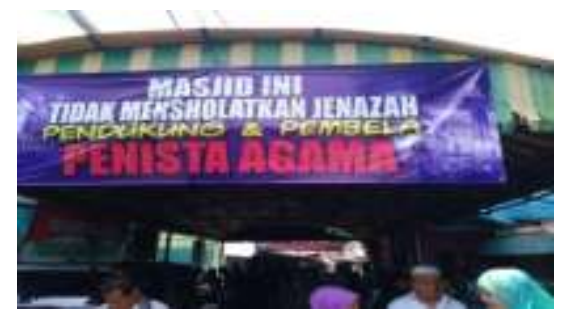

Sumber gambar: VOA-Islam.com

Allegedly from the coverage of 6.com that the rejection of the funeral service actually occurred among the people of Jakarta that year. The body of a 78-year-old grandmother was abandoned by the surrounding community. The reason is that the grandmother, who has been unable to walk for a long time, chose Basuki Tjahaja Purnama alias Ahok and Djarot Saiful Hidayat during the first round of the DKI Regional Election. ${ }^{16}$

Organizing the mobilization of the masses through their da'wah actions then leads to voting for leadership seats that are in line with Islamic principles. This means that indirectly the actions of the 411 movement have begun to be carried by political interests, the state must be in harmony with Islamic principles, especially in choosing a leader. ${ }^{17}$

${ }^{15}$ Ali Maskhan Moesa, Kiai NU dan Spirit Nasionalisme (Jogjakarta: LKJS, 2007), hal. 65.

${ }^{16}$ https://www.liputan6.com/news/read/2882270/jenazah-nenek-hindun-ditelantarkan-warga-setelah-pilih-ahok

17 Dalam hal memilih seorang pemimpin, umat Islam haruslah dipimpin oleh orang yang beragama Islam. Hal ini berdasarkan salah satu perintah yang tertulis dalam al qur'an maupun hadist. Namun Al Qur'an dan hadist tersebut menjadi problema tersendiri (menimbulkan diskriminasi) bagi negara yang menganut sistem demokrasi seperti Indonesia ini terlebih pada hak sosial non-muslim untuk menjadi seorang pemimpin. 
After Ahok stepped down from the leadership seat and was not elected in the second round, the direction of da'wah began to shift to the economic development sector through the 212 minimarket business and cooperatives. Not only that, the socio-religious movement is also still visible with the congregational dawn prayer agenda and the routine agenda of the 212 alumni with the same goal, namely trying to monitor government policies in regulating laws so that they are in line with Islamic values..

In 2019, the government issued a policy related to the disbanding of organizations that were deemed not in line with the principles of democracy and nationalism. One by one, religious figures who were considered as divisive people who were against the principles of democracy and nationalism began to be arrested under the pretext of disturbing the defense of the Unitary State of the Republic of Indonesia. Of course, this triggers anger for his followers who are members of the 212 alumni. So the news sheet "criminalization of ulama" also adorns the digital world. Then the direction of the indictment leads to the action of defending the clergy.

This action is not much different from the previous action, the beginning was peaceful. However, when their demands are not met, the peaceful action turns into anarchy. Again, here religious leaders in their da'wah succeeded in igniting the religious emotions of their followers to carry out these actions.

Indeed, since the fall of the New Order government in 1998, it has opened up freedom in the political, social and economic fields. The door of democracy is the main guide for the reform movement in the public sphere and provides a stage for social, political and religious activists or actors to discuss the formulation of the benefit of the people and the nation. One of the actors in this case is a religious activist consisting of (kyai, ulama, ustadz and religious leaders/religious instructors). Religious instructors are interpreters who convey messages to the community regarding the principles and ethics of good religious values. In addition, religious instructors are the spearhead in carrying out the task of guiding Muslims in achieving a quality and spiritual life.

Religious instructor is a professional field of work that requires certain skills and a very proud choice of work, because its presence in the community is very significant and necessary. They become inspirations, motivators, stabilizers and development dynamists in the midst of society. Moreover, the messages spread by religious activists are legitimized with religious arguments so that they seem to be much more effective. Because for religious people, especially Islam, implementing religious teachings in life is an obligation.

As stated by the sociologist Emile Durkheim In social life, religion has a function or role. The flow of functionalism views society as a social balance of intuition in which it is a social system of 
society that creates a social behavior consisting of norms that bind life. Here a belief or religion is only a human social behavior that is institutionalized among others which at the same time has a function on the whole social system. As stated by Durkheim that the social function of religion is to support and preserve the existing society. Where religion can provide inner peace in their lives. To overcome all the problems above, humans run to religion which is considered capable of overcoming all the problems of life. ${ }^{18}$

Belief in something that is considered sacred including religious teachings, scriptures and so on is a common phenomenon in human life and the natural surroundings, especially for religious people. A person's religion is strongly influenced by the local culture. If this theory is related to the diversity of the participants in the 411 action, it is undeniable that there are differences in interpreting religious teachings in each individual. For them, taking action on the streets is one of the religious orders that must be enforced at any cost. And they refuse to be considered as fundamentalists or radicals. Even if the actions taken are considered radical and anarchic when their demands are not met.

Religious emotions often enter into every individual who is religious when related to something sacred that is disturbed by others, in this case what Ahok is disturbing is one of $\mathrm{Al}$ Maidah's QS which is considered less relevant if applied in Indonesia, because it will cause discrimination. He realized that his election as Governor of Jakarta was not because of his intelligence capabilities, but because of the prevailing organizational system. He replaced the vacant Jakarta leadership chair, because his status at that time was Deputy Governor of Jakarta. In the initial inauguration process, there were pros and cons, many of the Muslims expressed their disapproval of Ahok being appointed as governor because he was not a Muslim. Whereas for him, Indonesia is a democratic country, so anyone has the right to be a leader regardless of ethnicity, religion and culture.

Furthermore, related to religion and its function from a functional point of view, Emile Durkheim explained that religious or religious practices carried out by religious adherents have a hidden function, namely to strengthen the identity of the group. Rizieq and his alliance are aware of this hidden function, he and his alliance take advantage of the role of digital media as a wider form of mass communication. ${ }^{19}$

${ }^{18}$ Ishomuddin. Pengantar sosiologi agama. (Jakarta: GHALIA INDONESIA, 2002),50-52.

${ }^{19}$ Beberapa tahun terakhir, dunia digital khususnya dunia media sosial menjelma sebagai alat jitu untuk menanamkan nilai nilai keagamaan secara intensif. Banyaknya postingan terkait dengan agama mulai diminati oleh sebagian besar masyarakat Indonesia tanpa melalui proses filter. Kegemaran akan dunia digital dan media sosial inilah yang kemudian dimanfaatkan oleh tokoh - tokoh agama untuk menerapkan idiologinya terhadap masyarakat yang lebih luas, tak hayalpun secara sadar atau tidak langsung akan membentuk follower. Dari sinilah kemudian terbentuk komunitas virtual yang di dalamnya ada ikatan solidaritas sosial yang terbentuk. 
The role of the media is indeed very important in the formation of the existing social reality. This is in accordance with the theory that the existing media are construction agents. In the positivist view, the media is considered purely as a channel. Media is a means of how messages are disseminated from the communicator to the recipient (audience). The media is only a place for how messages are transacted from all parties involved in the news. The media is seen as a neutral means. If there is news that mentions certain groups or describes reality with a certain image, such an image is the result of news sources (communicators) who use the media to express their opinions. What appears in the news is what actually happened. In short, the media here are not involved in shaping reality/facts, they are only a channel to describe the reality/facts.

In the constructionist view, the media is seen the opposite. The media is not just a free channel, it is also a subject that constructs reality, complete with views, biases, and sides. The news presented by the media does not necessarily describe reality, not only describes the opinions of news sources, but also how the construction of the media itself is related to the event. Media is an agent who actively interprets reality to be presented to the public. ${ }^{20}$

\section{c. Religious Sctivists are an Elite Group}

In people's lives there is an assumption that there will always be a need for a leader, so that people who are ruled will appear and govern others. In the relationship between governing and being ruled, there will be governing elites and non-governing elites which are then depicted through a pyramid image where under the two elite groups there are then what are called nonelite groups, which are more numerous than the two types of elite groups. With these advantages, the elite will be able to increase their role and influence in society.

As a center of strength and dynamic for the organization, a sense of unity in a particular society. Leaders must communicate with all parties both through formal and informal relationships, the success of the leader is largely determined by his ability to establish appropriate communication (dialogue) with all parties horizontally and vertically.

Basically these elite figures are divided into 2, namely: formal elites and informal elites (formal leaders or informal leaders). Formal elites are people who are appointed by certain organizations/institutions as leaders, based on decisions and official appointments to hold positions and organizational structures with all rights and obligations related to them to achieve

\footnotetext{
${ }^{20}$ Eriyanto. Analisis Framing. Konstruksi, Ideologi, dan Politik Media. Cet. 7. (Yogyakarta : Lkis. 2002), 26.
} 
organizational goals. While informal is a person who does not get a formal appointment as a leader, but because he has a number of superior qualities, he reaches a position as a person who is able to influence the psychological condition and behavior of a group or society. ${ }^{21}$

Religious activists in the 411 - GNPF MUI action are a group of local elites who have influence among Muslims. So it is not surprising that the efforts of the religious movement carried out by Rizieq at that time involved people who were considered to have more prestige in society, ranging from religious leaders, businessmen and political figures. It was noted that Amin Rais, Prabowo and even former Indonesian president Susilo Bambang Yudhoyono also participated in supporting the Rizieq movement which demanded Ahok be held accountable for his words, regardless of other goals.

Briefly from the above information, the author draws a common thread that the da'wah movement carried out by religious activists in 2016-2019 and their collective actions involving hundreds or even thousands of people who come from all over the archipelago cannot be separated from the role of social media. The use of social media by religious activists is considered significant enough to organize and mobilize the masses to participate in the field action. Establishing a virtual community is considered to be much more effective in establishing existing social solidarity, moreover the sense of social solidarity is based on the same identity, namely Islam.

The bond of social solidarity will be established by itself when the values that are considered sacred/religious have been disturbed by others. Because in the view of sociology, religion is the social glue of society. Especially Islam, under the pretext of preaching amar ma'ruf nahi Munkar and upholding sharia in Indonesia, religious activists will find it very easy to mobilize and mobilize a very large number of people, as in the 411-GNPF MUI action that took place in 2016-2019. The themes of da'wah vary, but all of them cannot be separated from the main goal, namely the kaffah application of sharia in Indonesia.

\section{CONCLUSION}

The case of blasphemy committed by Mr. Ahok in 2016 became the most popular news of all time in this digital era. The case has a long tail and raises pros and cons among the public, especially among Muslims. What's more, some of the Islamic mass organizations have accused them of taking down the streets with certain political interests. All efforts were made by these religious activists to hal 8.

${ }^{21}$ Kartini Kartotjio "Pemimpin dan Kepemimpinan; Apakah Pemimpin Abnormal Itu?". PT Raja Grafindo Persada. Jakarta 1998. 
QAULAN, Vol. 2, No.1, Juni 2021

Imam Mukhlis, Media as a Social Contract....

legally process Ahok, one of which was the call for jihad amar ma'ruf nahi munkar by utilizing several existing digital media.

Utilization of the development of information technology as a medium of da'wah has been put to good use by these religious activists. In an effort to organize a collective social movement, in this case a mass action involving thousands of Muslims from all over the archipelago, solidarity is needed. Thus, the sense of solidarity is able to foster an attitude in the form of sacrificing time, money, thoughts and energy for a common goal. To foster an attitude of solidarity involving hundreds of people from various regions in the archipelago, da'wah activists utilize existing technology media, especially social media.

\section{REFERENCES}

Ali Maskhan Moesa, Kiai NU dan Spirit Nasionalisme Jogjakarta: LKJS, 2007.

Ambo upe "tradisi aliran dalam sosiologi dari filosofi positivistic ke post positivistic" (Jakarta: PT RajaGrafindo persada,2010

Deddy Mulyana Pengantar Ilmu Komunikasi Bandung. Remaja Rosda Karya. 2005

Eriyanto. 2002. Analisis Framing - Konstruksi, Ideologi, dan Politik Media. Yogyakarta: LKIS.

Eriyanto. Analisis Framing. Konstruksi, Ideologi, dan Politik Media. Cet. 7. Yogyakarta : Lkis. 2002

Hajir Tajiri dan Enjang (ED). Etika Dakwah T.W. Padjadjaran, 2009

https://www.liputan6.com/news/read/2882270/jenazah-nenek-hindun-ditelantarkan-wargasetelah-pilih-ahok

Thohir, Umar Faruq. "Tasawuf Sebagai Solusi Bagi Problematika Kemodernan: Studi Pemikiran Tasawuf M. Amin Syukur." Jurnal Theologia 24.2 (2013): 43-68.

Thohir, Umar Faruq. "Konsep Tawakkal Dalam Perspektif Pasangan Perkawinan Anak di Desa Wedusan Probolinggo Jawa Timur." JURNAL HUKUM ISLAM (2019): 210-229.

Indra latif syaepu Kerukunan Antar Umat Beragama di Desa Besowo Kecamatan Kepung Kabupaten kediri: Studi Terhadap Peran Elit Lokal dan Masyarakat dalam Melestarikan Kerukunan. Universitas Islam Negeri Yogyakarta, 2016.

Indra latif Syaepu Radikal Dulu, Teroris Kemudian: Gerakan Islam "garis keras" dulu dan kini Dalam tinjauan sosial-historis STAIN Kediri: Emperisma juli 2017

Ishomuddin. Pengantar sosiologi agama. Jakarta: GHALIA INDONESIA, 2002 
QAULAN, Vol. 2, No.1, Juni 2021

Imam Mukhlis, Media as a Social Contract....

Kartini Kartotjio "Pemimpin dan Kepemimpinan; Apakah Pemimpin Abnormal Itu?". PT Raja Grafindo Persada. Jakarta 1998.

K.Notthingham elizabeth. "agama dan masyarakat suatu penghantar sosiologi agama". Jakarta: PT RajaGrafindo, 1994

Nasrullah, nazsir."teori-teori sosiologi”. Bandung: widya padjajaran,2008

Saputra, Munzier \& Harjani Hefni Metode Dakwah Jakarta: Prenamedia Group, 2015

Sugiyono, Metode Penelitian Kombinasi Mixed Methods Bandung: Alfabeta, 1953

Suharsini Arikunto, Prosedur Penelitian Suatu Pendekatan Praktek, Jakarta: Bhineka Cipta, 1998

Suprapto dalam Rachmat Jalalludin. Teori Komunikasi. Jakarta: Remaja Rosda Karya, 2004

Taufik Abdullah, Agama dan Perubahan Sosial Jakarta: CV Rajawali, 1983

The Indonesian Institute, Center for public policy research "Úpdate Indonesia" volume X No 11 November 2016 